\title{
Effects of Soil and Water Conservation at Different Landscape Positions on Soil Properties and Farmers' Perception in Hobicheka Sub-Watershed, Southern Ethiopia
}

\author{
Tamrat Sinore (iD) and Dinsa Doboch \\ Department of Natural Resource Management, Wachemo University, Hossana, Ethiopia \\ Correspondence should be addressed to Tamrat Sinore; tame.eiar@gmail.com
}

Received 16 August 2021; Accepted 27 October 2021; Published 10 November 2021

Academic Editor: Rafael Clemente

Copyright (c) 2021 Tamrat Sinore and Dinsa Doboch. This is an open access article distributed under the Creative Commons Attribution License, which permits unrestricted use, distribution, and reproduction in any medium, provided the original work is properly cited.

\begin{abstract}
This study aimed to evaluate the effects of soil and water conservation (soil bund with desho grass and soil bund only) at different landscape positions on selected soil properties and farmers' perception in the Hobicheka sub-watershed (with an area of 400 ha) of Kechabira District. Composite soil samples were taken from soil bunds with desho grass and soil bunds only at three landscape positions with three replications, whereas 117 respondents were identified using simple random sampling. The result revealed that the clay, soil moisture content, soil pH, OC, TN, Av.P, and CEC were higher in soil bund with desho grass as compared to adjacent soil bund only, whereas, bulk density, silt, and sand contents were higher in adjacent soil bund only compared to soil bund with desho grass. About $83.5 \%$ of the respondents were users of soil and water conservation measures and among them, $40.19 \%$ perceived that soil bund with desho grass has an effect on soil properties, while $25.35 \%$ perceived that soil bund only had better soil and water conservation practices. Respondents' years of experience, education level, and access to soil and water conservation extension services significantly $(p \leq 0.1)$ affected their perception of the use of soil bunds with desho grass. Therefore, soil bund with desho grass at appropriate landscape positions by considering farmer perception improves the soil's physicochemical properties.
\end{abstract}

\section{Introduction}

Soil productivity is deteriorating as a result of soil erosion, nutrient depletion, and organic matter depletion $[1,2]$, especially in the Ethiopian highlands. For example, each year, about $42 \mathrm{t} \mathrm{ha}^{-1}$ of fertile soil and essential plant nutrients are lost in Ethiopia due to poor soil management on cultivated lands. Changes in land use and soil management can have a dramatic impact on soil fertility [3], particularly the conversion of natural ecosystems to crop land, which has resulted in a loss in physical, chemical, and biological qualities of soil [4]. The consequences of more intensive farming and farming on steep slopes are declining fertility and the high incidence of soil loss due to erosion [5]. Cultivated soils do have low fertility status due to their high bulk density, low total porosity, low $\mathrm{pH}$, and very low organic carbon content [6-8].
To minimize soil deterioration and rehabilitate damaged lands, the Ethiopian government has previously initiated many soil conservation programs with the help of international aid and development agencies [9, 10], integrating nongovernmental organizations (NGOs) and local people. Different soil and water conservation technologies and practices have been deployed, particularly in Ethiopia's highlands, where the challenge is more daunting, including the Hobicheka sub-watershed. Soil conservation measures can change the physical conditions of the soil such as soil organic matter content, soil structure, water holding capacity, soil bulk density, soil porosity, soil $\mathrm{pH}$, and its workability $[11,12]$, and the emphasis of soil conservation measures in Ethiopia should be shifted away from the construction of bunds and toward the use of vegetative and agronomic measures that are the most effective measure in erosion control. 
The main challenges of soil and water conservation practices in Ethiopia include an emphasis on physical measures (soil bunds, Fanya-juu, and so on), implementing uniform technologies for all agro-ecologies, a failure to integrate physical measures with biological practices, a topdown extension approach, and a lack of attention to indigenous knowledge [13-15]. Because of the issues presented, soil and water conservation initiatives in Ethiopia, particularly the Hobicheka sub-watershed, have been less successful. Currently, the government recognizes the causes of failures in soil and water conservation efforts and focuses on integrating physical measures with biological practices (soil bund with desho grass), increasing community engagement at various stages, and promoting intact indigenous soil conservation practices. As a result, Smith [16] noted that public and private supporters deploy soil bunds with desho grass ( $P$. pedicellatum) across the slope in densely populated highlands for sustainable soil and water conservation programs, including the Hobicheka sub-watershed.

According to many scholars, desho grass is a member of the Poaceae family and also is native to tropical areas $[16,17]$. This grass has a big root system and produces a large amount of biomass per square meter [18]. The grass was discovered in Ethiopia in 1991 in the Chenecha District, Southern Region [17] and has since been widely used in various agro-ecologies [19]. This grass has been utilized to maintain soil bunds, protect croplands from soil erosion and degradation in Ethiopia's highlands [17, 20], rehabilitate degraded land [16], and improve grazing land and cattle feeding $[17,21]$. When compared to other grasses adopted for soil and water management strategies in Ethiopia (elephant, $P$. purpureum, vetiver, $V$. zizanioides), desho grass is one of the most desired for controlling erosion and rehabilitating degraded land [20]. Desho grass is undoubtedly widely distributed and employed for soil management practices in the Hobicheka sub-watershed and other nations with comparable agroecology, based on its grass character (root system) and different responsibilities (erosion control, land rehabilitation, cattle feed). However, farmers' use of soil bunds with desho grass to protect cropland from further erosion, rehabilitate degraded land, and feed cattle is limited, and the approaches are prohibited. In the Hobicheka subwatershed, there was limited information on the effects of soil and water conservation measures (soil bund with desho grass) on soil properties at different landscape positions by considering farmer perception. Therefore, this study was conducted with the following specific objectives (i) to evaluate the effects of soil bund with desho grass (P. pedicellatum) at various landscape positions on selected soil physicochemical properties and (ii) to assess farmers' perception on the integrated use of soil bund with desho grass for sustainable soil and water management in the study area.

\section{Materials and Methods}

2.1. Study Area Description. The study was conducted in Hobicheka sub-watershed in Kechabira district which is located in Kembata Tembaro Zone and $275 \mathrm{~km}$ away from
Addis Ababa [22]. It is geographically located between $37^{\circ}$ $31^{\prime} 30^{\prime \prime}$ to $37^{\circ} 49^{\prime} 0^{\prime \prime} E$ and the latitude of $07^{\circ} 12^{\prime} 0^{\prime \prime}$ to $07018^{\prime}$ $0^{\prime \prime} \mathrm{N}$ (Figure 1) with an area of 400 hectares.

The mean annual rainfall is $1000 \mathrm{~mm}$ to $1200 \mathrm{~mm}$ and temperature is between $15^{\circ} \mathrm{C}$ and $20^{\circ} \mathrm{C}$. The district consists of highland (Dega) 25\%, midland (Weynedega) 55\%, and lowland (Kolla) 20\% of agro-ecological zone, and the Vitric and Nitosol are the dominant soils in the district [22].

According to CSA [23], the district has a total population of 93,078 and their livelihood is mixed agriculture (crop and livestock production). The annual crops grown are wheat, teff, potatoes, barley, maize, pea, cabbage, carrots, and onions. Based on the land-use system, the dominant soil and water conservation measures introduced to the farmlands are physical soil and water conservation including soil bunds and biological measures, especially desho grass [22].

2.2. Method of Data Collection. Primary data for this study were collected through soil sampling, field observation, focus group discussion, Key informant, household interviews and secondary data were captured from published and unpublished sources.

2.2.1. Study Area Selection. Prior to actual work, a reconnaissance survey was conducted to identify the representative sample sites. After that, Hobicheka sub-watershed of Kechabira district was selected through purposive sampling for this study due to the existence of both similar 10-year aged soil and water conservation measures (soil bund with desho grass and adjacent soil bund only) implemented by communities to reduce soil erosion and enhance crop yield. According to the department head of natural resource management in Kechabira district Agricultural office, among the soil and water conservation measures implemented by the farmers were desho grass with soil bund, soil bund only, and other physical structures. As examining the effectiveness of soil and water conservation practices on soil properties was essential for promoting a sustainable environment, the soil bund treated with desho grass and adjacent soil bund only were considered for this study. Sustainability of conservation measures depends on the support of physical measures by biological measures (soil bund with desho grass), the slope of the land, construction quality, construction material, and appropriateness of the structure to the site conditions $[24,25]$.

2.2.2. Soil Sampling Techniques. To analyze the effect of soil and water conservation (soil bund with desho grass and soil bund only) on soil properties, composite soil samples were collected from farm land managed by soil bund with desho grass (10-year old) and adjacent soil bund only (10-year old) at various landscape positions. Based on the landscape positions, the farm land of the study watershed was categorized into three landscape positions, such as upper $(\geq 30 \%)$ landscape position, middle (15-30\%) landscape position, and lower (3-15\%) landscape position. There were two soil and water conservation (soil bund with desho grass and soil 


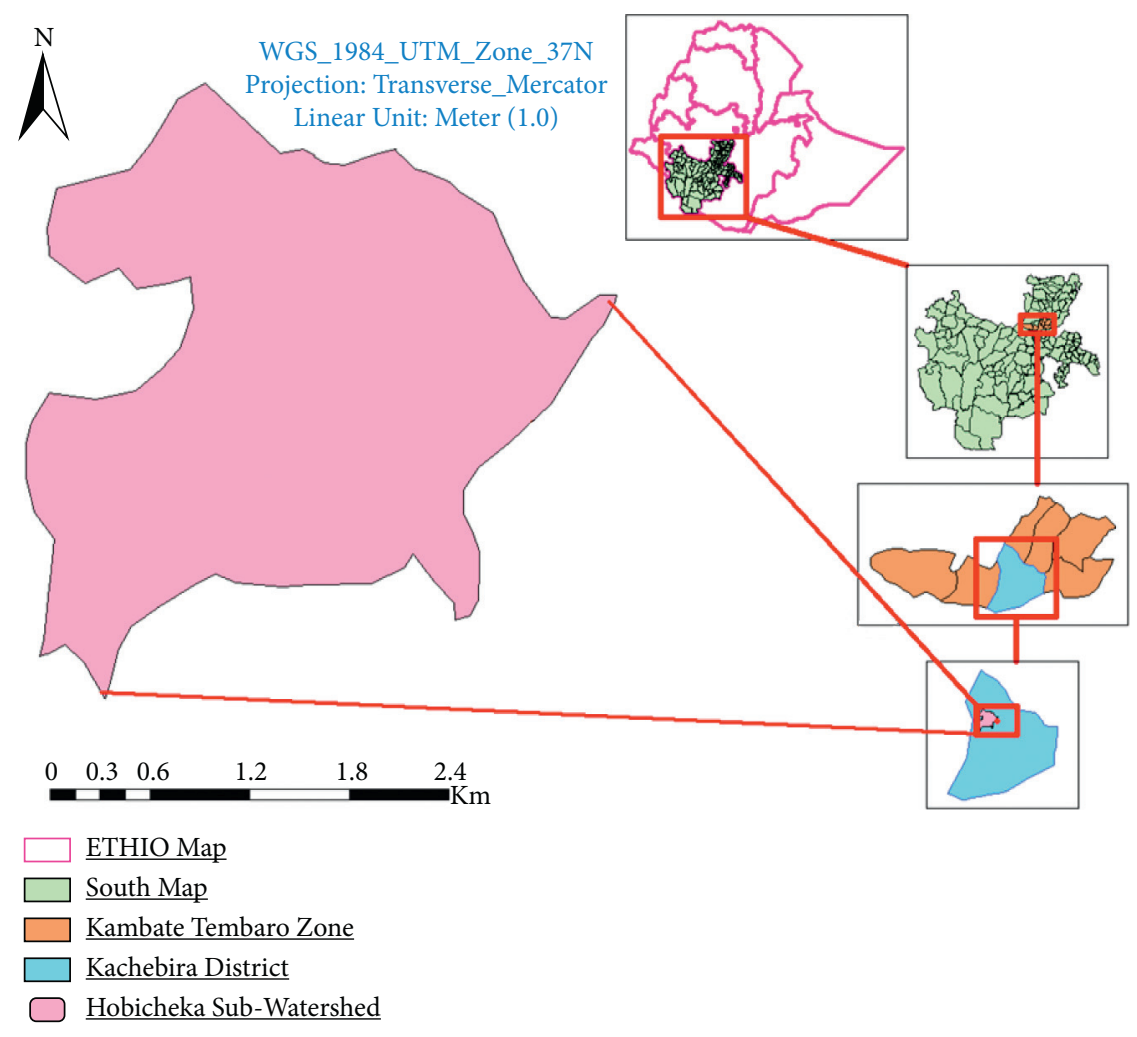

Figure 1: Map of the study area.

bund only) measures and three landscape positions with three replications considered for soil sampling. Accordingly, 18 total composite soil samples were collected from surface soil $(0-30 \mathrm{~cm})$ for laboratory analysis. The size of each plot from which the composite soil samples were taken was $3 \mathrm{~m} \times 6 \mathrm{~m}$ at $1 \mathrm{~m}$ away from the soil bund with size using " $\mathrm{X}$ " sampling design [26]. To determine soil bulk density, an undisturbed soil sample was collected using the core sampling method [27] from the cropland. In all cases, the history of soil and water conservation particularly of fertilizer application was recorded, and all interviewed farmers responded that they use the same type and amount of fertilizer per hectare on their farm land both for soil bund with desho grass and soil bund only. The farm lands from where the soil samples were taken were under barley cultivation.

2.2.3. Household Survey. To assess the farmers' perception on soil and water conservation (soil bund with desho grass and soil bund only) measures in the study area, a structured questionnaire was used to collect data from households. Factors related to farmers' perception towards implementing the soil and water conservation practices on their landholdings were collected from Focus Group Discussions, key informant interviews, field observations, and selected household interviews using structured questionnaires. Accordingly, 117 households were selected through simple random sampling. The sample size was determined using Cochran's [28] probability proportional to sample size sampling technique.

$$
\begin{aligned}
& n_{0}=\frac{Z^{2}(p)(q)}{d^{2}}, \\
& n_{1}=\frac{n_{0}}{\left(1+n_{0} / N\right)},
\end{aligned}
$$

where $n_{\mathrm{o}}=$ desired sample size of Cochran's [28] when population is greater than $10,000, n_{1}=$ finite population correction factor [28] less than $10,000, Z=$ standard normal deviation (1.96 for 95\% confidence level), $p=0.1$ (proportion of population to be included in sample, i.e., 10\%), $q=1-p=(1-0.1)=0.9, N=$ total number of population, and $d=$ degree of accuracy desired (0.05)

117 farmers were sampled for the interview with an error margin of $5 \%$, and the probability of the sample size has a confidence interval of $95 \%$.

2.2.4. Soil Laboratory Analysis. The soil samples were airdried, mixed thoroughly, and passed through a $2 \mathrm{~mm}$ screen to determine the texture, bulk density, and moisture content. A hydrometer method was used to determine particle size distribution [29]. To destroy the soil organic matter, hydrogen peroxide $\left(\mathrm{H}_{2} \mathrm{O}_{2}\right)$ was utilized. Sodium hexametaphosphate $\left(\mathrm{NaPO}_{3}\right)_{6}$ and sodium carbonate $\left(\mathrm{Na}_{2} \mathrm{CO}_{3}\right)$ were also used as soil dispersants, along with one or two drops of amyl alcohol for foam reduction. A core method [27] was used to determine the bulk density of the undisturbed soil samples and by weighing the core weight of a solid and water content, and drying at a temperature of $105^{\circ} \mathrm{C}$ for 24 hours at a constant weight and calculated as: 


$$
\mathrm{BD}=\frac{\mathrm{Mcs}-\mathrm{Mc}}{\mathrm{Vc}}
$$

where $\mathrm{BD}=$ bulk density in $\mathrm{gcm}^{-3}, \mathrm{Mcs}=$ the mass of each core with its dry soil in $g, M c=$ the mass of each empty core in $g$, and $\mathrm{Vc}=$ volume of core in $\mathrm{cm}^{3}$.

Soil moisture content can be determined by using the gravimetric method.

$$
\text { Percent of moisture }(w t \%)=\frac{A-B}{B-C} \times 100,
$$

where $A$ = weight of wet soil in gram + tin weight, $B=$ weight of oven dry soil in gram + tin weight, and $C=$ weight of the empty tin.

In the supernatant suspension of the ground, soil $\mathrm{pH}$ was determined with the glass electrode method $1: 2.5$ : mass-tovolume liquid. The $\mathrm{pH}$ meter has been calibrated as necessary earlier than usage with $\mathrm{pH} 7$ buffer solution. After 30 minutes of churning, the soil $\mathrm{pH}$ was checked using a standard $\mathrm{pH}$ meter, and the solution was water. The wet digestion method developed by Walkley and Black was used to determine soil organic carbon. Soil $(1 \mathrm{~g})$ was reacted with $10 \mathrm{~mL}$ of $1 \mathrm{~N} \mathrm{~K}_{2} \mathrm{Cr}_{2} \mathrm{O}_{7}$ solution and $20 \mathrm{~mL}$ of $98 \% \mathrm{H}_{2} \mathrm{SO}_{4}$. The excess dichromate solution was titrated with $1 \mathrm{M}$ ferrous sulphate after the addition of $200 \mathrm{~mL}$ distilled water, $10 \mathrm{~mL}$ of $85 \%$ phosphoric acid, and $1 \mathrm{~mL}$ of indicator solution ( $0.16 \%$ barium diphenylamine sulphate), and finally, multiply the soil organic carbon by 1.724 to get soil organic matter, assuming that organic matter is made up of $58 \%$ carbon [30]. The available phosphorus content of the soil was analyzed using $0.5 \mathrm{M}$ sodium bicarbonate extraction solution $(\mathrm{pH}<7)$ using the Bray II method [31]. Total nitrogen was identified by using the Kjeldahl digestion procedure [32]. Cation exchange capacity (CEC) was determined after extracting the soil samples by the ammonium acetate method ( $\left.1 \mathrm{~N} \mathrm{NH}_{4} \mathrm{OAc}\right)$ at $\mathrm{pH} 7.0$ [29].

2.3. Data Analysis. Using SAS 9.2, the Analysis of Variance (ANOVA) tool was used to examine the variations in soil parameters caused by different soil and water conservation (SWC) practices at the $p<0.05$ level. The mean was separated using the least significant difference (LSD) at $p<0.05$. The relative change was utilized to determine how much the soil attributes changed as a result of stabilized soil bund with desho grass as compared to soil bund only by using the following formula:

$$
\text { relative change }=\frac{\left(P_{s}-P_{g}\right)}{P_{g}} \times 100,
$$

where $P_{s}$ is the soil property measured on the soil bund with desho grass and $P_{g}$ is the soil property measured on the adjacent soil bund only.

The data from the household survey were analyzed using the Statistical Package for Social Science (SPSS) version 20 software. Descriptive statistics were employed to describe the examined data, and the chi-square test was utilized to determine whether there were any significant variations in respondents' perceptions of SWC practice (user and nonuser groups). The drivers of farmers' perceptions of the use of SWC practices were investigated using a logistic regression model.

2.3.1. Identification of Variables and Empirical Models. Logistic regression is a commonly used statistical approach for studying farmers' perceptions of conservation technologies [33]. It provides for the prediction of a discrete outcome from a set of factors that can be continuous, discrete, dichotomous, or a combination of these. The dependent variable (i.e., perception of soil and water conservation techniques) is a dichotomous discrete variable obtained as a binary response from the questionnaire survey, while an independent factor is a mixture of discrete and continuous variables. Following the method of Refs. [34, 35], the logistic regression model reflecting the perception of the sample households was generated and specified as:

$$
P i=F(\alpha+\beta X i)=\frac{1}{1+e^{-(\alpha+\beta X i)}},
$$

where $i$ denotes the $i$ th observation in the sample; $\mathrm{Pi}$ is the probability that an individual will make a certain choice given $\mathrm{Xi} ; e$ is the base of natural logarithms and approximately equal to 2.718 ; $\mathrm{Xi}$ is a vector of exogenous variables; variables $\alpha$ and $\beta$ are parameters of the model; $\beta 1, \beta 2 \ldots \ldots$, $\beta \mathrm{k}$ are the coefficients associated with each explanatory variable $\mathrm{X} 1, \mathrm{X} 2, \ldots, \mathrm{Xn}$.

The above function can be rewritten as: $\ln [P /(1-P)]=\beta$ $0+\beta 1 X 1+\beta 2 X 2+\ldots+\beta k X k$

where the quantity $P /(1-P)$ is the odds (likelihoods); $\beta 0$ is the intercept; $\beta 1, \beta 2 \ldots$ and $\beta k$ are coefficients of the associated independent variables of $X 1, X 2 \ldots$ and $X k$. It is important to highlight that the computed coefficients reflect the effect of individual explanatory factors on the log of chances $\ln [\mathrm{P} /(1-\mathrm{P})]$. The study's independent variables are expected to be related to farmers' perceptions of soil erosion and conservation activities. To be more specific, previous research findings on farmers' perceptions, existing theoretical explanations, and the researcher's understanding of the farming systems in the study area were used to choose explanatory variables. The definition and units of measurement of the dependent and explanatory variables were used in the logistic regression model and are presented in Table 1.

\section{Results and Discussion}

\subsection{Soil Physical Properties}

3.1.1. Texture. Both SWC strategies (soil bund with desho grass and soil bund only) had a substantial $(p \leq 0.05)$ effect on the soil textural fractions (clay and sand) (Table 2) except silt contents. The soil bund with desho grass had the highest mean value of clay content $(54.44 \pm 9.5)$, while the adjacent soil bund only had the lowest $(37.67 \pm 5.24)$ (Table 2$)$. The highest clay percentage in the soil bund with desho grass was due to desho grass improving ground cover and the erosion resistance of clay particles, which reduces the clay fraction. 
TABLe 1: Definition and units of measurement of the variables included in the model $(n=117)$.

\begin{tabular}{lccc}
\hline Variables & Variable code & Variable type & Unit of measurement \\
\hline $\begin{array}{l}\text { Dependent } \\
\text { Perception of SWC }\end{array}$ & PRSWC & Dummy & 1 if perceived erosion can be controlled; 0 otherwise \\
$\begin{array}{l}\text { Explanatory } \\
\text { Age of household head }\end{array}$ & Age & Dummy & 1 if productive, 0 otherwise in year \\
Gender of respondents & Gender & Dummy & 1 if male, 0 if female \\
Education level of respondents & EDUC & Dummy & 1 if literate; 0 otherwise \\
Family size of respondents & FMSZ & Continuous & Measured in number \\
Land size of respondents & LNDSZ & Continuous & Measured in hectare \\
Livestock size of respondents & LVSK & Continuous & Measured in TLU \\
Access to extension service of respondents & ACCESS & Dummy & 1 if the farmer get extension service; 0 otherwise \\
Distance of farm land from their residence & DISTNCE & Dummy & 1 if far; 0 otherwise \\
\hline
\end{tabular}

TABle 2: The mean effects of soil and water conservation and landscape position on selected soil physical properties (Mean \pm SE).

\begin{tabular}{|c|c|c|c|c|c|}
\hline \multirow{2}{*}{ SWC measures } & \multicolumn{5}{|c|}{ Soil physical properties } \\
\hline & Clay (\%) & Silt (\%) & Sand $(\%)$ & $\mathrm{BD}\left(\mathrm{g} / \mathrm{m}^{3}\right)$ & SMC (\%) \\
\hline SBD & $54.44 \pm 9.5^{\mathrm{a}}$ & $18.44 \pm 3.9^{\mathrm{a}}$ & $26.88 \pm 7.23^{\mathrm{b}}$ & $1.12 \pm 0.08^{\mathrm{a}}$ & $20.73 \pm 2.84^{\mathrm{a}}$ \\
\hline SBO & $37.67 \pm 5.24^{\mathrm{b}}$ & $23.97 \pm 3.44^{\mathrm{a}}$ & $37.89 \pm 6.13^{\mathrm{a}}$ & $1.21 \pm 0.65^{\mathrm{b}}$ & $15.78 \pm 1.59^{b}$ \\
\hline LSD (0.05) & 6.37 & 3.86 & 5.65 & 0.07 & 1.92 \\
\hline$p$ value & 0.0001 & 0.091 & 0.0009 & 0.03 & 0.0001 \\
\hline Relative change (\%) & 44.52 & 23.1 & -29.1 & -7.4 & 31.4 \\
\hline \multicolumn{6}{|l|}{ Landscape position } \\
\hline Upper $(\geq 30 \%)$ & $40.66 \pm 12.3^{\mathrm{b}}$ & $22 \pm 6.44^{\mathrm{a}}$ & $37 \pm 8.27^{\mathrm{a}}$ & $1.18 \pm 1.18$ & $16.55 \pm 2.91^{\mathrm{a}}$ \\
\hline Middle (15-30\%) & $45.5 \pm 11.1^{\mathrm{ab}}$ & $21.5 \pm 3.01^{\mathrm{a}}$ & $32.83 \pm 9.17^{\mathrm{ab}}$ & $1.15 \pm 1.15$ & $18.31 \pm 3.35^{\mathrm{ab}}$ \\
\hline Lower (3-15\%) & $52 \pm 9.5^{\mathrm{a}}$ & $20 \pm 4.1^{\mathrm{a}}$ & $27.33 \pm 6.62^{b}$ & $1.15 \pm 1.15$ & $19.91 \pm 3.54^{\mathrm{b}}$ \\
\hline LSD $(0.05)$ & 7.8 & 4.7 & 6.92 & 0.11 & 2.35 \\
\hline$p$ value & 0.023 & 0.65 & 0.031 & 0.74 & 0.027 \\
\hline $\mathrm{CV}(\%)$ & 13.68 & 18.03 & 17.26 & 6.36 & 10.41 \\
\hline
\end{tabular}

Means within a column followed by the same letter are not significantly different ( $p>0.05)$, otherwise it is significant. LSD : least significant difference, CV: coefficient of variance, SWC: soil and water conservation, SBD : soil bund with desho grass, and SBO : soil bund only.

In contrast, the lowest clay content in the adjacent soil bund involved the removal of the clay particles, thereby increasing the proportion of the coarser particles in the soil, which leaves more sand particles. Sinore et al. [36] reported that clay particles are lighter than sand particles, and once detached by erosion they are easily transported. However, the highest silt and sand $(23.97 \pm 3.44$ and $37.89 \pm 6.13)$ contents were observed in soil bund only and the lowest contents were observed in soil bund with desho grass (18.44 \pm 3.9 and $26.88 \pm 7.23$ ) (Table 2 ). This might be greater soil bund cover with desho grass as mulch improves soil organic matter, which is reflected in the reduction of silt and sand content in the soil bund with desho grass site.

Statistical analysis revealed that sand and clay fractions were significantly $(p \leq 0.05)$ affected by landscape position in the upper $(\geq 30 \%)$ and lower (3-15\%) landscape positions, while the silt fraction was not significant (Table 2). The recorded mean values of clay and sand fractions in the upper $(\geq 30 \%)$ landscape positions were $40.66 \pm 12.3$ and $37 \pm 8.27$, while the mean values of clay and sand fractions in the lower (3-15\%) landscape positions were $52 \pm 9.5$ and $27.33 \pm 6.62$, respectively (Table 2 ). More sand material remains in the upper slope positions due to the removal of clay fraction from the upper slope positions and depositing it on the lower slope positions. This was in line with Umer et al. [15], who reported that at the upper slope position, the soil bund managed with grass strips had better clay than the soil bund alone. Soil bunds stabilized with grass contribute a higher proportion of clay particles than the bund alone [37] and fine materials are selectively removed from the upper slope and deposited on the lower slope [38].

3.1.2. Soil Bulk Density (BD). Because of the contribution of desho grass to the soil, both SWC techniques (soil bund with desho grass and soil bund only) had a significant $(p \leq 0.05)$ effect on soil bulk density (Table 2 ). The soil bund with desho grass had the lowest mean value of soil bulk density and the adjacent soil bund had the highest mean value $\left(1.112 \mathrm{~g} / \mathrm{m}^{3}\right.$ and $1.21 \mathrm{~g} / \mathrm{m}^{3}$ ), respectively (Table 2). The relative change indicated that the soil bulk density in the soil bund with desho grass was reduced by $7.4 \%$ when compared to the adjacent soil bund only (Table 2). This is owing to the increased proportion of organic matter and clay in the soil under soil bunds with desho grass. This was consistent with the findings of Bezabih et al. [39] and Demelash and Karl [40], who found that the mean value of bulk density within the conserved farm lands with SWC practice was lower than in nonconserved farm lands, owing to the decomposition of plant biomass on the conserved field increasing organic matter contents, which reduces soil bulk density. There was no statistically significant $(p>0.05)$ variation in soil bulk 
density (BD) between landscape positions (Table 2). The highest mean value of soil bulk density $\left(1.18 \pm 1.18 \mathrm{~g} / \mathrm{m}^{3}\right)$ was recorded in soil bund only at the upper $(\geq 30 \%)$ landscape position and the lowest mean value $(1.15 \pm 1.15)$ was observed in the soil bund with desho grass at the lower (3-15\%) landscape position (Table 2).

3.1.3. Soil Moisture Content (SMC). The soil moisture content (SMC) was significantly $(p \leq 0.05)$ different between the two SWC measures (soil bund with desho grass and soil bund only) (Table 2). The highest mean value of SMC $(20.73 \pm 2.84)$ was observed in soil bund with desho grass and the lowest mean value $(15.78 \pm 1.59)$ was recorded in soil bund only, respectively (Table 2 ). The relative change was shown such that there was an increment of SMC in soil bund with desho grass by $31.4 \%$ compared with adjacent soil bund only (Table 2). The probable reason was the higher organic matter built up in desho grass and the higher clay percentage of the soil in the soil bund with desho grass which has contributed to the higher moisture retention of the soil. In line with this finding, Sahoo et al. [41] reported that the grass can increase the moisture content of the soil due to higher input of organic matter into the soil. The analysis revealed that the soil moisture content (SMC) was significantly $(p \leq 0.05)$ affected by landscape positions in the upper $(\geq 30 \%)$ and lower (3-15\%) positions (Table 2$)$. The highest mean value of soil moisture content (SMC) on the lower (3-15\%) landscape position was $19.91 \pm 3.54$, while the lowest mean value recorded in the upper $(\geq 30 \%)$ landscape position was $16.55 \pm 2.91$ (Table 2) because the organic carbon contents of the study areas increase from the upper slope to lower parts of the catchment and this may be due to the difference in soil erosion rates. The soil bund with desho grass may reduce the probability of evaporation by increasing surface cover, and down movement of soil nutrients along the slope positions resulted in a high deposition of soil materials in the lower slopes which contribute the greatest amount of soil moisture content recorded under soil bund with desho grass of the lower slope. The root systems of the desho grass conserve soil moisture through minimizing erosion, evaporation, surface runoff, and modifying soil microenvironment $[15,21]$, and variations in topography conservation measures and soil attributes affect the distribution of soil moisture content.

\subsection{Soil Chemical Properties}

3.2.1. Soil $p H$. As presented in Table 3, the mean value of soil $\mathrm{pH}(p \leq 0.05)$ was significantly different between both SWC measures (soil bund with desho grass and soil bund only). The highest mean value of soil $\mathrm{pH}(6.58 \pm 0.16)$ was observed in the soil bund with desho grass, while the lowest mean value $(5.67 \pm 0.21)$ was recorded in the adjacent soil bund only, respectively. The lowest soil $\mathrm{pH}$ at the adjacent soil bund only might be because of the loss of basic cations through leaching and draining by runoff generated on crop land, whereas the highest mean of soil $\mathrm{pH}$ on soil bund with desho grass might be because of the addition of organic matter from desho grass, litters, and recycling basic cations from deeper soil layers to the top surface by its fine root structure. The relative change showed that the $\mathrm{pH}$ value increased by $16 \%$ in the soil bund with desho grass compared to the adjacent soil bund only. The improvement of soil $\mathrm{pH}$ can bring improvement on selected soil chemical properties because $\mathrm{pH}$ controls all chemical reactions in the soil. The study revealed that there is a significant $(p \leq 0.05)$ difference in the soil $\mathrm{pH}$ among landscape positions (Table 3). The highest mean value of soil $\mathrm{pH}(6.31 \pm 0.47)$ was observed in the lower (3-15\%) landscape position, and the lowest mean value $(5.95 \pm 0.49)$ was observed in the upper $(\geq 30 \%)$ landscape position (Table 3), which might be attributed to the removal of some organic matters from steep slope and deposition on the lower slope. Moreover, erosion can significantly accumulate soluble ions from the upper slope and deposit on the lower slope positions where leaching is weaker and soil enrichment is stronger. This finding was supported by Esayas [42] and Mohammed et al. [43] who reported that the soil in high altitude and those with higher slopes had low $\mathrm{pH}$ values than lower slope positions because of the washing out of solutes and basic cations from these parts.

3.2.2. Organic Carbon. As presented in Table 3, soil organic carbon, total nitrogen, and available phosphorus were significantly $(p \leq 0.05)$ affected by both SWC measures (soil bund with desho grass and soil bund only) in the study area. The highest mean value of soil organic carbon $(4.01 \pm 0.44)$ was recorded in the soil bund with desho grass and the lowest mean value $(1.84 \pm 0.88)$ was observed in the adjacent soil bund only. The reason for significantly higher OC in the soil bund with desho grass was the extensive root system that anchors soil particles and high biomass production capacity in the soil. Desho grass contributes to soil chemical property advancement by anchoring soil particles with its large root system, high biomass production capacity, and return organic matter to the soil [18], minimize and control soil nutrient loss $[17,20]$, and rehabilitate degraded soil [16]. The relative change showed that OC value increased by $117.9 \%$ in the soil bund with desho grass compared to the adjacent soil bund only (Table 3). This implies that the soil bund with desho grass has good physical (structural condition and high structural stability) and chemical conditions. The variation of soil organic carbon was significantly $(p \leq 0.05)$ different in relation to a landscape position (Table 3 ). The result has shown that the highest mean value of OC $(3.66 \pm 0.87)$ was recorded in the lower (3-15\%) landscape positions, followed by the middle (15-30\%) and upper ( $\geq 30 \%)$ landscape positions with a mean value of $2.85 \pm 1.25$ and $2.24 \pm 1.48$, respectively (Table 3). This is in agreement with Buyinza and Nabalegw [44] who reported that concentrations of OC were higher in the middle and lower slope positions than in the upper slope positions.

3.2.3. Total Nitrogen and Available Phosphorus. The results revealed that the mean values of total nitrogen and available phosphorus were significantly $(p \leq 0.05)$ affected by both SWC measures (soil bund with desho grass and adjacent soil 
TABLE 3: The mean effects of soil and water conservation measures and landscape positions on selected soil chemical properties (Mean \pm SE).

\begin{tabular}{|c|c|c|c|c|c|}
\hline \multirow{2}{*}{ SWC measures } & \multicolumn{5}{|c|}{ Soil chemical properties } \\
\hline & $\mathrm{pH}-(\mathrm{H} 2 \mathrm{O})$ & OC (\%) & TN (\%) & Av.P (ppm) & $\mathrm{CEC}(\mathrm{cmol} / \mathrm{kg})$ \\
\hline SBD & $6.58 \pm 0.16^{\mathrm{a}}$ & $4.01 \pm 0.44^{\mathrm{a}}$ & $0.41 \pm 0.05^{\mathrm{a}}$ & $18.93 \pm 3.6^{\mathrm{a}}$ & $40.94 \pm 0^{\mathrm{a}}$ \\
\hline SBO & $5.67 \pm 0.21^{\mathrm{b}}$ & $1.84 \pm 0.88^{\mathrm{b}}$ & $0.27 \pm 0.04^{\mathrm{b}}$ & $14.2 \pm 2.02^{\mathrm{b}}$ & $27.24 \pm 0^{\mathrm{b}}$ \\
\hline LSD (0.05) & 0.11 & 0.35 & 0.02 & 0.09 & 6.37 \\
\hline$p$ value & 0.0001 & 0.0001 & 0.001 & 0.0001 & 0.0001 \\
\hline Relative change (\%) & 16 & 117.9 & 51.85 & 33.3 & 50.3 \\
\hline \multicolumn{6}{|l|}{ Landscape position } \\
\hline Upper $(\geq 30 \%)$ & $5.95 \pm 0.49^{c}$ & $2.24 \pm 1.48^{\mathrm{c}}$ & $0.29 \pm 0.06^{\mathrm{c}}$ & $13.82 \pm 1.7^{\mathrm{c}}$ & $29.25 \pm 5.48^{\mathrm{c}}$ \\
\hline Middle (15-30\%) & $6.11 \pm 0.54^{\mathrm{b}}$ & $2.85 \pm 1.25^{\mathrm{b}}$ & $0.35 \pm 0.08^{\mathrm{b}}$ & $16.62 \pm 2.8^{\mathrm{b}}$ & $33.6 \pm 8.46^{\mathrm{b}}$ \\
\hline Lower (3-15\%) & $6.31 \pm 0.47^{\mathrm{a}}$ & $3.66 \pm 0.87^{\mathrm{a}}$ & $0.39 \pm 0.08^{\mathrm{a}}$ & $19.23 \pm 4.4^{\mathrm{a}}$ & $39.41 \pm 8.83^{\mathrm{a}}$ \\
\hline LSD $(0.05)$ & 0.13 & 0.43 & 0.02 & 2.28 & 2.44 \\
\hline$p$ value & 0.0001 & 0.0001 & 0.0001 & 0.0007 & 0.0001 \\
\hline CV (\%) & 1.85 & 12.01 & 5.54 & 9.41 & 5.78 \\
\hline
\end{tabular}

Means within a column followed by the same letter are not significantly different ( $p>0.05)$, otherwise they are significant. SWC: soil and water conservation, SBD : soil bund with desho grass; SBO : soil bund only.

bund only) (Table 3). The highest mean values of total nitrogen content and available phosphorus $(0.41 \pm 0.05$ and $18.93 \pm 3.6)$ were recorded in soil bund with desho grass and the lowest $(0.27 \pm 0.04$ and $14.2 \pm 2.02)$ were recorded in adjacent soil bund only (Table 3 ). The nutrient availability improved through recycling of the biomass back into the soil and decomposition of OM from desho grass may be the reason for the significant enhancement of the amount of TN and Av. P in the soil bund with desho grass. The relative change of TN and Av. P under soil bund with desho grass and adjacent soil bund alone was increased by $51.85 \%$ and $33.49 \%$, respectively (Table 3 ). The variation of TN and Av. P were significantly $(p \leq 0.05)$ different in relation to a landscape position (Table 3 ). The highest mean value of TN and Av. P $(0.39 \pm 0.08$ and $19.23 \pm 4.4)$ were recorded in the lower (3-15\%) landscape positions, whereas the lowest mean values $(0.29 \pm 0.06$ and $13.82 \pm 1.7)$ were observed in the upper $(\geq 30 \%)$ landscape positions (Table 3 ). This is due to the slope controlling the movement of soil material in a hill slope, and it contributes to the spatial differences of soil properties which might be due to limited organic matter that make better conditions for soil microorganisms used to breakdown other fresh organic matter so that the phosphorous present in the form of immobility can be changed into plant available forms. The result is in agreement with Buyinza and Nabalegw [44] who reported that areas protected with grass had an increasing trend in total nitrogen and available phosphorus from the upper slope to the foot slope position.

3.2.4. Cation Exchange Capacity (CEC). The study revealed that cation exchange capacity was significantly affected by both SWC measures (soil bund with desho grass and soil bund only) and landscape position in the study area (Table 3). The highest mean value of CEC $(40.94 \pm 0)$ was observed in soil bund with desho grass and the lowest mean value $(27.24 \pm 0)$ was recorded in soil bund only while the relative change was increased by $50.3 \%$ in contrast to the soil bund only (Table 3 ). The most probable reason might be attributed to the increment in exchangeable cations, OM, and clay contents under soil bund with desho grass. It is a well-known fact that both clay and colloidal OM can absorb and hold positively charged ions. Soils with a high clay and OM content have a high CEC. In agreement with this, Kibret [45] observed that soil CEC is connected with clay and OM colloids, with OM rendering soils having a higher CEC. There was a statistically significant $(p \leq 0.05)$ difference in CEC based on landscape position. The lowest mean value of CEC $(29.25 \pm 5.48)$ was reported in the lower $(3-15 \%)$ landscape position, while the highest mean value $(39.41 \pm 8.83)$ was observed in the upper ( $\geq 30 \%)$ landscape position (Table 3 ). The probable reason for the substantially higher CEC in the lower (3-15\%) slope managed with soil bund with desho grass was because of the basic cations on the upper $(\geq 30 \%)$ slope position that moved to the lower slope positions and accumulated on foot slope position due to erosion and the contribution of organic matter from desho grass and crop residues. Bahilu et al. [46] reported in agreement with this study that a high mean value of CEC was obtained at the lower slope position of land covered by grass and a low mean value was obtained at grazing land on the upper slope position.

\subsection{Farmers' Perception on the Use of Soil and Water Conservation Practices}

3.3.1. Farmers' Perception on Soil Erosion. Care of the farmers' soil erosion in the study area is one of the most important conditions for assessing their perception of soil and water conservation measures. As presented in Figure 2, about $83.5 \%$ of the respondents were users of soil and water conservation measures on their crop land to minimize the risk of soil erosion, whereas $16.5 \%$ of respondents were nonusers of soil and water conservation on their own cropland. Among the soil and water conservation users, $20.36 \%, 50.28 \%, 9.41 \%$, and $3.40 \%$ describe the rates of soil erosion on their cropland as severe, moderate, minor, and none, respectively. Of the nonuser groups, $2.7 \%, 5.27 \%$, $5.12 \%$, and $3.41 \%$ perceived soil erosion as severe, moderate, minor, and none, respectively. Hence, most of the respondents perceived a soil erosion problem on their own 


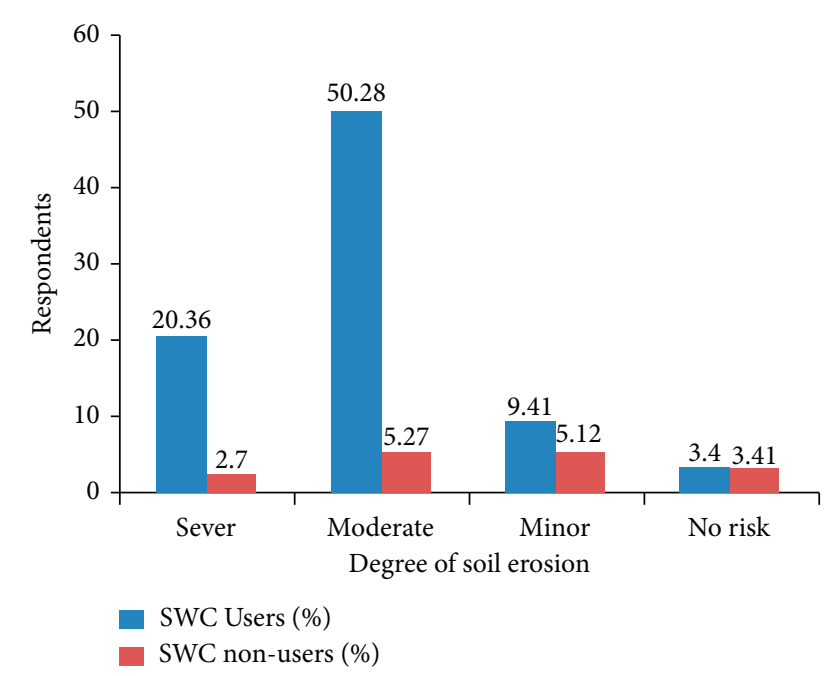

FIGURE 2: Farmers' perception on the severity of soil erosion in the study area $(n=117)$.

farms. This has shown that most of the respondents reported the rate of soil erosion on their farm as moderate due to practicing different soil and water conservation practices in the study area. This agreed with the report of Detamo [47] in Soro Woreda that about $65.5 \%$ of respondents opined that the degree of soil erosion on their farm land was moderate and $4.8 \%$ and $29.8 \%$ of respondents mentioned erosion on their farm as none and minor, respectively.

As presented in Figure 2, most of the respondents who practiced soil and water conservation measures in the study area were educated farmers and the rest were illiterate. Detamo [47] reported that the level of expression of the soil erosion problems shows differences between educated and uneducated farmers. This shows that illiterate farmers differ in perceiving soil erosion problems compared with educated farmers, and that with an increasing level of educational attainment of farmers, there is a higher perception of soil erosion problems. For instance, almost all farmers who attained education perceived the existence of soil erosion as well and practiced soil conservation measures on their cropland. Therefore, as a result of their educational level, uneducated farmers are likely to differ in practicing soil conservation measures compared with educated farmers.

Furthermore, focus group participants and key informants stated that soil erosion rates in the research area were moderate. In addition, they reported that the topographic character of the farmland, absence of fallowing, crop residue removal, free grazing, and runoff from upslope were the main causes of soil erosion in the study area; unsuitable farming and the easily erodible nature of the soil were some of the difficulties. According to Bewket [48], the first step in searching for soil and water conservation strategies is to recognize soil erosion as a concern and understand its causes and impacts on crop yields.

3.3.2. Farmers' Perception on Soil and Water Conservation Practices. As presented in Table 4, about $40.19 \%$ of the respondents were involved in integrated soil and water conservation (soil bund with desho grass), $25.35 \%$ of the respondents practiced physical soil and water conservation measures alone (soil bunds only), and $17.96 \%$ practiced biological measures alone such as desho grass strips, whereas $16.5 \%$ of the respondents were nonusers of any of the soil and water conservation practices in the study area. The reasons why farmers did not use soil and water conservation were uncontrolled grazing, distance of farm land from their residence, limited contact with development agents, involvement in off-farm activates, and having a gentle slope of farm land. Farmers reported that from November to May, our croplands were free. This meant uncontrolled grazing by livestock and respondents being involved in off-farm activity, which did not give them time to contact development agents to acquire skills and knowledge regarding soil and water conservation practices in the study area.

Farmers did not integrate soil bund with desho grass as a soil and water conservation measure on their farms due to a lack of education, small farm size, uncontrolled livestock grazing, the nature of the landform, and limited contact with development agents, according to focus group participants and key informants. Educated farmers were more likely to use soil bunds with desho grass as SWC measures than uneducated farmers; also, small farm sizes limit farmers' ability to use this multipurpose grass species as a SWC; farmers with small farm sizes prioritize crop production over soil and water conservation measures. Amsalu and Graaff [49] similarly observed that farmers with a larger farm are more willing to invest in soil conservation techniques since they are subsidized, while farmers with a small area prefer crop production. The results of the chi-square suggest a substantial difference $\left(X^{2}=0.000\right.$ at $\left.p \leq 0.01\right)$ between users and nonusers of soil and water conservation techniques on their farms.

Focus group participants and key informants revealed that communities in the study area have a positive perception towards integrating soil bund with desho grass for improving soil organic matter by reducing further soil loss and runoff velocity. In addition to this, the farmers of the study area were benefitted, especially fodder from the desho grass. This made respondents to have a positive perception on this desho grass species in the study area.

3.3.3. Factors Affecting Perception of Farmers to Apply Integrated Soil and Water Conservations. The regression model's overall predictions indicated that dependent (such as perception of integrated soil bund with desho grass as SWC) and explanatory variables (such as age, gender, educational level, family size, land size, livestock size, and access to extension service) adequately explained the farmer's perception of integrated use of soil and water conservation practices. The study found a significant relationship between farmer's perception and the group of explanatory variables $\left(R^{2}=0.7371\right)$ (Table 5$)$. The predicted positive coefficient in the logistic regression model for age, education level, family size, land holding size, and access to extension service of household imply an increase in these explanatory variables (such as age, education level, family size, land holding size, and access to extension service) and 
only. This showed the positive influence of SWC measures in improving nutrient status, which in turn plays a great role in benefiting stakeholders at large, whereas soil bulk density, silt, and sand content were higher in soil bund only at upper $(\geq 30 \%)$ landscape position compared to soil bund with desho grass.

On the other hand, about $83.5 \%$ of the respondents were users of soil and water conservation measures, and among them, $40.19 \%$ perceived soil bund with desho grass to have great effects on soil physicochemical properties, while $25.35 \%$ perceived soil bund only had better soil and water conservation practices. The reason why they preferred soil bunds with desho grass was that the desho grass adds litter, anchors, and improves soil properties. This made respondents have a positive understanding of integrated soil and water conservation. Among the explanatory variables, household head age, education level, and access to soil and water conservation extension services significantly $(p \leq 0.1)$ affected the community's perception of soil bund with desho grass as SWC. Therefore, practicing soil bund with desho grass in the appropriate landscape positions by considering farmers' perception improves soil physicochemical properties. To better understand the effects of the said practices on the soil environment, more research is needed on the amount of sediments trapped by soil bunds with desho grass, micronutrient improvement, and soil health improvements.

\section{Data Availability}

The analysed data during the current study are available from the corresponding author on reasonable request.

\section{Conflicts of Interest}

Authors reported no potential conflicts of interest.

\section{Authors' Contributions}

TS was in charge of the design, approach, formal analysis, inquiry, initial draft writing, and presentation. DD was involved in the concept, approach, review writing, and editing.

\section{Acknowledgments}

The authors would like to thank Wachemo University for subsidizing the study, as well as the farmers in the Hobicheka sub-watershed for their assistance in data gathering.

\section{References}

[1] A. K. Hadera and H. Gebrekidan, "Soil acidity characterization and effects of liming and chemical fertilization on dry matter yield and nutrient uptake of wheat (Triticum aestivum L.) on soils of Tsegede District, Northern Ethiopia," Doctoral dissertation, Haramaya University, Dire Dawa, Ethiopia, 2013.

[2] F. R. Akamigbo and C. A. Asadu, "The influence of parent materials on the soils of Southeastern Nigeria," East African Agricultural and Forestry Journal, vol. 48, pp. 81-91, 2001.
[3] A. P. Aluko and J. A. Fagbenro, "The role of tree species and land use systems in organic matter and nutrient availability in degraded Ultisol of Onne, Southeastern Nigeria," in Proceedings of the 26th Annual Conference Soil Science, pp. 220-236, Ibadan, Nigeria, November 2000.

[4] T. Adugna, M. Siraj, and B. Eve, "Effects of soil and water conservation structures on selected soil physicochemical properties: the case of ejersa lafo district, central highlands of Ethiopia," Applied and Environmental soil science, vol. 2021, Article ID 9910237, 11 pages, 2021.

[5] B. Shiferaw and S. T. Holden, "Resource degradation and adoption of land conservation technologies in the Ethiopian highlands: a case study in Andit Tid, North Shewa," Agricultural Economics, vol. 18, no. 3, pp. 233-247, 1998.

[6] J. Chorowicz, B. Collet, F. F. Bonavia, P. Mohr, J. F. Parrot, and T. Korme, "The Tana basin, Ethiopia: intra-plateau uplift, rifting and subsidence," Tectonophysics, vol. 295, no. 3-4, pp. 351-367, 1998.

[7] M. Díaz-Raviña, J. Bueno, S. J. González-Prieto, and T. Carballas, "Cultivation effects on biochemical properties, C storage and $15 \mathrm{~N}$ natural abundance in the $0-5 \mathrm{~cm}$ layer of an acidic soil from temperate humid zone," Soil and Tillage Research, vol. 84, no. 2, pp. 216-221, 2005.

[8] P. R. Day, "Particle fractionation and particle-size analysis," Methods of Soil Analysis: Part 1 Physical and Mineralogical Properties, Including Statistics of Measurement and Sampling, vol. 9, pp. 545-567, American Society of Agronomy, Madison, WA, 1965.

[9] T. Hawando, "Desertification in Ethiopian highlands," vol. 75-86, Norwegian Church AID, Oslo, Norway, 1997, Rala Report No. 200.

[10] K. Wolka, "Effect of soil and water conservation measures and challenges for its adoption: Ethiopia in focus," Journal of Environmental Science and Technology, vol. 7, no. 4, pp. 185-199, 2014.

[11] T. Erkossa, "Land preparation methods and soil quality of a vertisol area in the central highlands of Ethiopia," Doctoral dissertation, University of Hohenheim, Stuttgart, Germany, 2005.

[12] E. Elias, Farmers' Perceptions of Soil Fertility Change and Management, SOS Sahel and Institute for Sustainable Development, Addis Ababa, Ethiopia, 2002.

[13] H. Mitiku, H. Karl, and S. Brigitta, "Sustainable land management: a new approach to soil and water conservation in Ethiopia," vol. 304, 2006.

[14] A. Bekele, A. Abebayehu, and K. Endalkachew, "Assessment of community based watershed management practices: emphasis on technical fitness of physical structures and its effect on soil properties in Lemo district, Southern Ethiopia," Environmental Systems Research, vol. 7, no. 1, pp. 1-11, 2018.

[15] S. Umer, A. Abebayehu, and K. Endalikachew, "Effects of integrated use of grass strip and soil bund on soil properties, Southern Ethiopia," Journal of Degraded and Mining Lands Management, vol. 6, no. 2, Article ID 1569, 2019.

[16] G. Smith, Ethiopia: Local Solutions to a Global Problem, Retrieved from View, 2010.

[17] S. Welle, C. Korchoke, N. Supakij, and J. Somjate, "Effectiveness of grass strips as barrier against runoff and soil loss in Jijiga area, northern part of Somali region, Ethiopia," Agriculture and Natural Resources, vol. 40, no. 2, pp. 549-558, 2006.

[18] K. S. Ramirez, C. L. Lauber, R. Knight et al., "Consistent effects of nitrogen fertilization on soil bacterial communities in 
contrasting systems," Ecology, vol. 91, no. 12, pp. 3463-3470, 2010 .

[19] G. Leta, J. Alan Duncan, and A. Asebe, "Desho grass (Pennisetum pedicellatum) for livestock feed, grazing land and soil and water management on small-scale farms," 2013.

[20] G. Yakob and A. Addis, "Participatory evaluation of different multipurpose grass species for graded soil bund stabilization in Gimbo district, South West Ethiopia," Open Access Library Journal, vol. 2, no. 6, 2015.

[21] D. Danano, Improved Grazing Land management-Ethiopia, pp. 313-316, Where The Land Is Greener. WOCAT, Bern, Switzerland, 2007.

[22] KWAO (Kechabira Woreda Agricultural Office), Land Use Type Profiles and Annual Reports, (unpublished), 2017.

[23] CSA (Central Statistical Authority), Statistical Abstract of Ethiopia, Central Statistical Authority, Addis Ababa, Ethiopia, 2007.

[24] Q.-J. Zhang, B.-J. Fu, L.-D. Chen et al., "Dynamics and driving factors of agricultural landscape in the semiarid hilly area of the Loess Plateau, China," Agriculture, Ecosystems and Environment, vol. 103, no. 3, pp. 535-543, 2004.

[25] J. R. Olarieta, F. L. Rodríguez-Valle, and E. Tello, "Preserving and destroying soils, transforming landscapes: soils and landuse changes in the Vallès County (Catalunya, Spain) 18532004," Land Use Policy, vol. 25, no. 4, pp. 474-484, 2008.

[26] R. Margesin and F. Schinner, Manual for Soil AnalysisMonitoring and Assessing Soil Bioremediation, Vol. 5, Springer Science and Business Media, , Berlin, Germany, 2005.

[27] FAO, Methods of Analysis for Soils of Arid and Semi-arid Regions, Food and Agriculture organization of the United Nations Rome, Rome, Italy, 2007.

[28] W. G. Cochran, Sampling Technique, Vol. 442, John Wiley and Sons, New York, NY, USA, 3rd ed. edition, 1977.

[29] V. J. G. Houba, J. J. Van der Lee, I. Novozamsky, and I. Walinga, Soil and Plant Analysis, a Series of Syllabi, Part 5, Soil Analysis Procedures, Wageningen Agricultural University, Wageningen, Netherlands, 1989.

[30] D. W. Nelson and L. E. Sommers, "Total carbon, organic carbon, and organic matter," in Methods of Soil Analysis. Part 3. Chemicals Methods, D. L. Sparks, Ed., pp. 961-1010, ASA and SSSA, Madison, WI, USA, 1996.

[31] L. P. Van Reeuwijk, Procedures for Soil Analysis, International Soil Reference and Information Center Wageningen, Wageningen, Netherlands, 3rd ed edition, 1993.

[32] J. M. Bremner and D. L. Sparks, Methods of soil analysis, vol. 5, Soil Science of America and American Society of Agronomy, SSSA Book Series Madison-USA, Madison, WI, USA, 1996, Part 3.Chemical methods.

[33] B. Shiferaw and S. Holden, "Soil erosion and smallholders' conservation decisions in the highlands of Ethiopia," World Development, vol. 27, no. 4, pp. 739-752, 1999.

[34] A. Demeke, Factors Influencing the Adoption of Soil Conservation Practices in Northwestern Ethiopia, University of Goettingen, Goettingen, Germany, 2003.

[35] M. Denboba, Forest Coversion-Soil Degradation-Farmers Perception Nexus: Implications for Sustainable Land Use in the Southwest of Ethiopia, Cuvillier Verlag, vol. 26, , 2005.

[36] T. Sinore, E. Kissi, and A. Aticho, "The effects of biological soil conservation practices and community perception toward these practices in the Lemo District of Southern Ethiopia," International soil and water conservation research, vol. 6, no. 2, pp. 123-130, 2018.

[37] T. Amare, A. Terefe, Y. G. Selassie, B. Yitaferu, B. Wolfgramm, and H. Hurni, "Soil properties and crop yields along the terraces and toposequece of Anjeni Watershed, Central Highlands of Ethiopia," Journal of Agricultural Science, vol. 5, no. 2, p. 134, 2013.

[38] S. K. Tripathi and K. P. Singh, "Ecological responses of dry tropical forest and savanna ecosystems to nutrient enrichment," in Environment and Agriculture: Biodiversity, Agriculture and Pollution in South Asia, P. K. Jha, S. K. Baral, S. B. Karmacharya, H. D. Lekhak, P. Locoul, and C. B. CB Baniya, Eds., pp. 150-157, Ecological Society of Nepal, Kathmandu, Nepal, 2001.

[39] B. Bezabih, A. Aticho, T. Mossisa, and B. Dume, "Effect of land management practices on soil physical and chemical properties in Gojeb sub-river basin of Dedo district, Southwest Ethiopia," Journal of Soil Science and Environmental Management, vol. 7, no. 10, pp. 154-165, 2016.

[40] M. Demelash and S. Karl, "Assessment of integrated soil and water conservation Structures on key soil properties in South Gonder, North-Western Highlands of Ethiopia," Journal of Soil Science and Environmental Management, vol. 1, pp. 164-176, 2010.

[41] K. N. Sahoo, K. Ashwani, S. Satyawati, and S. N. Naik, "Interaction of Jatropha curcas plantation with ecosystem," in Proceedings of the International Conference on Energy and Environment, pp. 19-21, Chandigarh, India, June 2009.

[42] A. Esayas, "Some physico-chemical characteristics of the Raya valley report," Ethiopian Journal of Natural Resources, vol. 3, pp. 179-193, 2001.

[43] A. Mohammed, P. A. L. Le. Roux, C. H. Barker, and G. Heluf, "Soils of Jelo Micro-catchment in the chercher highlands of Eastern Ethiopia: I morphological and physicochemical properties," Ethiopian Journal of Natural Resources, 2005.

[44] M. Buyinza and M. Nabalegwa, "Effect of slope position and land-use changes to bio-physical soil properties in Nakasongola pastoral rangeland areas, Central Uganda," Soil Erosion Issues in Agriculture, INTECH Open Access Publisher, London, UK, 2011.

[45] M. Kibret, Enclosure as a viable option for rehabilitation of degraded lands and biodiversity conservation: the case of Kallu woreda, southern Wello, PhD Diss., M. Sc. Thesis, Addis Ababa University, Addis Ababa, Ethiopia, 2008.

[46] B. Bezabih, M. Lemenih, and A. Regassa, "Soil fertility status as affected by different land use types and topographic positions: a case of Delta sub-watershed, Southwestern Ethiopia," Journal of Biology, Agriculture and Healthcare, vol. 4, no. 27, pp. 91-105, 2014.

[47] K. Detamo, "Farmers perception on Soil Erosion and Their use of Structural Soil Conservation measures in Soro District, SNNPR Ethiopia," MEd Thesis, Addis Ababa University, Addis Ababa, Ethiopia, 2011.

[48] W. Bewket, Land Degradation and Farmers' Acceptance and Adoption of Conservation Technologies in the Digil Watershed, Northwestern Highlands of Ethiopia, Organisation for Social Science Research in Eastern and Southern Africa, Addis Ababa, Ethiopia, 2003.

[49] A. Amsalu and J. De. Graaff, "Determinants of adoption and continued use of stone terraces for soil and water conservation in an Ethiopian highland watershed," Ecological Economics, vol. 61, no. 2-3, pp. 294-302, 2007.

[50] D. A. Zegeye, Assessment of upland erosion processes and farmer's perception of land conservation in Debre-Mewi Watershed, Near Lake Tana, Ethiopia, Cornell University, Ithaca, NY, USA, PhD diss, 2009.

[51] A. J. Tenge, J. De Graaff, and J. P. Hella, "Social and economic factors affecting the adoption of soil and water conservation in 
West Usambara highlands, Tanzania," Land Degradation and Development, vol. 15, no. 2, pp. 99-114, 2004.

[52] M. Z. Semgalawe, Household Adoption Behaviour and Agricultural Sustainability in the Northeastern Mountains of Tanzania: The Case of Soil Conservation in the North Pare and West Usambara Mountains, Wageningen University and Research, Wageningen, Netherlands, 1998.

[53] A. Paulos, Determinants of Farmers' Willingness to Participate in Soil Conservation Practices in the Highlands of Bale: The Case of Dinsho Farming System Area, Vol. 14, Alemaya University, , Dire Dawa, Ethiopia, 2002.

[54] W. Bekele, Economics of soil and water conservation Theory and Empirical application to subsistence farming in the Eastern Ethiopian highlands, Swedish University of Agricultural Sciences, Uppsala, Sweden, PhD diss, 2003. 